\title{
A New Pathway Mediating Social Effects on the Endocrine System: Female Presence Acting via Norepinephrine Release Stimulates Gonadotropin-Inhibitory Hormone in the Paraventricular Nucleus and Suppresses Luteinizing Hormone in Quail
}

\author{
Dibasuko Tobari, ${ }^{1}$ You Lee Son, ${ }^{1}$ (D Takayoshi Ubuka, ${ }^{1}$ Yoshihisa Hasegawa, ${ }^{2}$ and Kazuyoshi Tsutsui ${ }^{1}$ \\ ${ }^{1}$ Laboratory of Integrative Brain Sciences, Department of Biology and Center for Medical Life Science, Waseda University, Shinjuku-ku, Tokyo 162-8480, \\ Japan, and ${ }^{2}$ Experimental Animal Science, School of Veterinary Medicine and Animal Sciences, Kitasato University, Aomori 034-8628, Japan
}

Rapid effects of social interactions on transient changes in hormonal levels are known in a wide variety of vertebrate taxa, ranging from fish to humans. Although these responses are mediated by the brain, neurochemical pathways that translate social signals into reproductive physiological changes are unclear. In this study, we analyzed how a female presence modifies synthesis and/or release of various neurochemicals, such as monoamines and neuropeptides, in the brain and downstream reproductive hormones in sexually active male Japanese quail. By viewing a female bird, sexually active males rapidly increased norepinephrine (NE) release in the paraventricular nucleus (PVN) of the hypothalamus, in which gonadotropin-inhibitory hormone (GnIH) neuronal cell bodies exist, increased GnIH precursor mRNA expression in the PVN, and decreased luteinizing hormone (LH) concentration in the plasma. GnIH is a hypothalamic neuropeptide that inhibits gonadotropin secretion from the pituitary. It was further shown that GnIH can rapidly suppress LH release after intravenous administration in this study. Centrally administered NE decreased plasma LH concentration in vivo. It was also shown that NE stimulated the release of GnIH from diencephalic tissue blocks in vitro. Fluorescence double-label immunohistochemistry indicated that $\mathrm{GnIH}$ neurons received noradrenergic innervations, and immunohistochemistry combined with in situ hybridization have further shown that GnIH neurons expressed $\alpha 2 \mathrm{~A}$-adrenergic receptor mRNA. These results indicate that a female presence increases NE release in the PVN and stimulates GnIH release, resulting in the suppression of LH release in sexually active male quail.

Key words: bird; monoamine; neurochemical pathway; neuropeptide; social signal; visual stimuli

\section{Introduction}

Social animals receive multiple forms of sensory information, and specific sexual signals trigger appropriate behavioral responses for reproduction (Robinson et al., 2008; Maruska and Fernald, 2011). Although these responses are mediated by the brain, the neural mechanisms that translate social signals into reproductive physiological and behavioral changes are unclear. Secretion of luteinizing hormone (LH) from the anterior pitu-

Received Aug. 29, 2013; revised May 20, 2014; accepted June 12, 2014.

Author contributions: Y.T. and K.T. designed research; Y.T., Y.L.S., T.U., and Y.H. performed research; Y.T. and K.T. contributed unpublished reagents/analytic tools;Y.T., Y.L.S., T.U., and Y.H. analyzed data; Y.T., Y.L.S., T.U., Y.H., and K.T. wrote the paper.

This study was supported by Scientific Research Grants from the Moritani Scholarship Foundation (Y.T.) and Grants-in-Aid for Scientific Research 22700446 (Y.T.), 18107002 (K.T.), 22132004 (K.T.), and 22227002 (K.T.) from the Ministry of Education, Science, Culture, and Technology of Japan. We thank Y. Fukuda and T. Mizuno (Waseda University) for their technical support.

The authors declare no competing financial interests.

Correspondence should be addressed to Dr. Kazuyoshi Tsutsui, Laboratory of Integrative Brain Sciences, Department of Biology and Center for Medical Life Science of Waseda University, 2-2 Wakamatsu-cho, Shinjuku-ku, Tokyo 162-8480, Japan. E-mail: k-tsutsui@waseda.jp.

DOI:10.1523/JNEUROSCI.3706-13.2014

Copyright $\odot 2014$ the authors $\quad 0270-6474 / 14 / 349803-09 \$ 15.00 / 0$ itary into the bloodstream that maintains testosterone secretion from the testis in males is stimulated by gonadotropin-releasing hormone $(\mathrm{GnRH})$ released from the hypothalamus (Matsuo et al., 1971; Burgus et al., 1973). Conversely, gonadotropin-inhibitory hormone $(\mathrm{GnIH})$ that was first identified in the hypothalamus of Japanese quail (Coturnix japonica) inhibits gonadotropin secretion from the pituitary (Tsutsui et al., 2000). GnIH has also been identified in numbers of vertebrate species (Kriegsfeld et al., 2006; Tsutsui, 2009; Tsutsui et al., 2010). In the avian brain, GnIH neurons are localized in the paraventricular nucleus (PVN) of the hypothalamus with their fibers located in the neurosecretory zone of the median eminence (Tsutsui et al., 2000). Recent studies have suggested that $\mathrm{GnIH}$ expression is influenced by social status and breeding condition (Ubuka et al., 2005; Calisi et al., 2011).

Monoamines, such as norepinephrine (NE), dopamine (DA), and serotonin (5-HT), are also candidates that translate social information into individual reproductive functions (Naumenko et al., 1987; Cornil et al., 2005). It was shown that visual signals during social interaction can universally evoke changes in monoaminergic activity in lizards, birds, and mammals (Fuchs et al., 1996; Korzan et al., 2000, 2008; Cornil et al., 2005). 
Japanese quail is an excellent animal model for studying the neuroendocrine control mechanism of reproductive physiology and behavior according to its social milieu (Ball and Balthazart, 2010). In male Japanese quail, visual cues appear to be of primary importance in the perception of social context. It is known that the presence of a female bird as well as copulation rapidly decrease plasma testosterone levels in male quail (Delville et al., 1984; Cornil et al., 2009). However, little is known about the neural mechanisms of how social interaction with a female acutely decreases plasma testosterone concentration. Here, we investigated how a female presence modifies important neurochemicals for reproduction, such as monoamines and neuropeptides, in the brain that regulate downstream reproductive hormones of male quail.

\section{Materials and Methods}

Animals. Japanese quail at 3 months of age were used in this study. All birds were maintained in a long-day photoperiod (16/8 h light/dark cycle; lights on at 7:00 A.M.). All subjects were sexually mature as demonstrated by regular egg laying in females and by an enlarged cloacal gland in males. The size of the cloacal gland, which is closely correlated with size of the testes and plasma testosterone level, provides an external marker of circulating testosterone concentration (Sachs, 1967; Ball and Balthazart, 2010). Birds were provided with food and water ad libitum. They were housed in individual cages in one room. Each bird had visual contact with other birds of the same sex. Experiments were approved by the Ethics Committee for the Use of Animals at Waseda University, Tokyo, Japan.

Experimental design. Adult male quail were used to investigate the effect of a female presence on changes in reproductive physiological and behavioral patterns. The test cage $(28 \mathrm{~cm}$ high $\times 60 \mathrm{~cm}$ long $\times 45 \mathrm{~cm}$ wide) was located in an empty room. It was divided in the middle with a transparent Plexiglas wall that physically separates the birds at both sides, but the birds can view each other freely. Five minutes after the experimental male was placed in one side of the cage, a stimulus bird was added to the other side of the cage, except for the isolated group birds (control), and kept for $60 \mathrm{~min}$. The stimulus bird was unfamiliar with the experimental male in all cases. A laying female or a male of the same age was used as the stimulus. The stimulus females and males were also maintained in a 16/8 $\mathrm{h}$ light/dark cycle and housed separately from the experimental males. Experimental male quail were immediately decapitated within $5 \mathrm{~min}$ after the end of the test session for analyses of monoamine concentrations and gene expressions of GnRH-I and GnIH in the diencephalon and plasma LH concentration. Diencephalic tissue was dissected by two coronal cuts at the level of the tractus septopalliomesencephalicus (rostral edge of the preoptic area) and the oculomotor nerves (caudal edge of hypothalamus), one parasagittal cut placed $\sim 2$ $\mathrm{mm}$ lateral to the midline and one horizontal cut $\sim 5 \mathrm{~mm}$ above the floor of the brain. Diencephalic tissue was collected and frozen in liquid nitrogen. Blood samples were immediately placed in heparinized tubes and centrifuged at $5000 \times g$ for $25 \mathrm{~min}$ at $4^{\circ} \mathrm{C}$. Harvested plasma and diencephalic tissue were stored at $-80^{\circ} \mathrm{C}$ until assay. All procedures were performed between 9:00 A.M. and 12:30 P.M.

Real-time quantitative PCR. Total RNA in the diencephalon was extracted using Sepasol-RNA I Super G (Nacalai Tesque), treated with DNase I recombinant RNase-free (Takara Bio), and purified. Two micrograms of total RNA were reverse transcribed into cDNA via incubation with random hexamer primers and MMLV (Promega) at $42^{\circ} \mathrm{C}$ for 60 min. The reaction mixture contained Thunderbird qPCR Mix (Toyobo), $300 \mathrm{~nm}$ each forward and reverse primers (Table 1), $1 \times$ ROX reference dye, and cDNA (equivalent to $8 \mathrm{ng}$ of reverse-transcribed RNA) in a final volume of $20 \mu$ l. RT-qPCR was conducted using the StepOnePlus system (Applied Biosystems). All samples were analyzed in duplicate with the following protocol: $95^{\circ} \mathrm{C}$ for $1 \mathrm{~min}$, followed by 40 cycles of $95^{\circ} \mathrm{C}$ for $15 \mathrm{~s}$ and $60^{\circ} \mathrm{C}$ for $60 \mathrm{~s}$. An external standard curve was generated by serial 10 -fold dilutions of plasmid constructs containing the relevant sequences (GnIH, GnRH-I, and 18S rRNA). The PCR products were sub-
Table 1. Primers used for real-time PCR and to make in situ hybridization probe

\begin{tabular}{|c|c|c|}
\hline Gene & Primer sequences & GenBank accession number \\
\hline \multicolumn{3}{|l|}{ Real-time PCR } \\
\hline Quail GnIH & & AB820136 \\
\hline Forward & 5'-ATGGTGCGTGCCTAGATGAAC-3' & \\
\hline Reverse & 5'-AGCAACTGAATTTGGCACTTTG-3' & \\
\hline Quail GnRH-I & & AB820137 \\
\hline Forward & 5'-GCTTGGCTCAACACTGGTCTT-3' & \\
\hline Reverse & 5'-GGGCATTCAGCCTCCTTCA-3' & \\
\hline Quail 18S rRNA & & AF173611 \\
\hline Forward & 5'-TGATTAAGTCCCTGCCCTTT-3' & \\
\hline Reverse & $5^{\prime}$-CCGAGGACCTCACTAAACCA-3' & \\
\hline \multicolumn{3}{|c|}{ In situ hybridization probe } \\
\hline Quail ADR $\alpha 2 A$ & & AB820133 \\
\hline Forward & 5'-CCACGTCCTGGTCATCATTG-3' & \\
\hline Reverse & 5'-ATGACGAAGACCCCAATCAC-3' & \\
\hline Quail ADR $\alpha 2 C$ & & AB820134 \\
\hline Forward & 5'-CTCTGGTCATGCCTTTCTCC-3' & \\
\hline Reverse & $5^{\prime}$-TCCCGGCAAATACCATAGAG-3' & \\
\hline
\end{tabular}

jected to a melting curve analysis, gel electrophoresis, and DNA sequencing to confirm specificity of the amplification. $18 \mathrm{~S}$ rRNA was used as internal control. The expression of GnIH and GnRH-I genes in each reaction was normalized by the expression of $18 \mathrm{~S}$ rRNA, using StepOnePlus 2.0 software (Applied Biosystems).

Cannulation, GnIH administration, and blood collection. Cannulation from the right jugular vein to the right atrium of the heart was performed at least $3 \mathrm{~d}$ before the experiment, and the cannula was filled with $10 \%$ heparin in physiological saline. At the time of the experiment, the $0 \mathrm{~min}$ blood sample of $300 \mu \mathrm{l}$ was collected, and the bird was administered 10 $\mathrm{ng}$ of $\mathrm{GnIH}$ in $100 \mu \mathrm{l}$ of physiological saline or vehicle. Blood samples of $300 \mu \mathrm{l}$ were collected, and the cannula was filled with $1 \%$ heparin in physiological saline at 5, 10, and $60 \mathrm{~min}$ after the administration of $\mathrm{GnIH}$ or vehicle. All experiments were performed from 10:00 A.M. until 12:00 P.M. The blood samples were centrifuged at $300 \times g$, and the plasma was collected and stored at $-20^{\circ} \mathrm{C}$ until assay for the measurement of $\mathrm{LH}$.

Analysis of diencephalic monoamine concentrations. The concentrations of monoamines [NE, epinephrine (Epi), DA, 5-HT, 3,4-dihydroxyphenylacetate (DOPAC), 5-hydroxyindoleacetic acid (5-HIAA), homovanillic acid (HVA), 3-methoxy-4-hydroxyphenylglycol (MHPG), and normetanephrine (NM)] in the diencephalon including the PVN were measured by HPLC electrochemical detection (ECD-300; Eicom). The diencephalic tissue $(100 \mathrm{mg})$ was homogenized in $0.2 \mathrm{M}$ perchloric acid, maintained on ice for $30 \mathrm{~min}$, and centrifuged at $20,000 \times g$ for 15 min as described previously (Matsunaga et al., 2004). The concentrations of monoamines in the supernatant were measured and expressed as micrograms per gram of tissue.

Microdialysis. Microdialysis was performed with a slight modification of our previous method (Ubuka et al., 2014). Male quail were deeply anesthetized with an intramuscular injection of pentobarbital $(40 \mathrm{mg} / \mathrm{kg}$ body weight) and placed in a stereotaxic apparatus (David Kopf Instruments). A guide cannula (AG-8; Eicom) was implanted stereotaxically into the brain $1 \mathrm{~mm}$ above the PVN (1.5 mm anterior, $0.5 \mathrm{~mm}$ lateral from the Y-point and $5.8 \mathrm{~mm}$ deep from the surface of the dura matter) and fixed to the skull with dental cement. An obturator was inserted into the guide cannula until microdialysis experiments began. Three to $5 \mathrm{~d}$ after surgery, the microdialysis probe (A-I-8-1; $1 \mathrm{~mm}$ membrane length; Eicom) was slowly inserted into the PVN through the guide cannula. Quail were then settled in the experimental cage. The probe was perfused continuously at a flow rate of $10 \mu \mathrm{l} / \mathrm{min}$ with Ringer's solution containing $147.0 \mathrm{~mm} \mathrm{NaCl}, 4.0 \mathrm{~mm} \mathrm{KCl}$, and $2.3 \mathrm{~mm} \mathrm{CaCl}_{2}$ for $3 \mathrm{~h}$ to wash out possible plugging of the membrane pore in the microdialysis probe by probe insertion and then $1 \mu \mathrm{l} / \mathrm{min}$ for $1 \mathrm{~h}$ to stabilize dialysis before collecting samples at the flow rate of $1 \mu \mathrm{l} / \mathrm{min}$. For determining female presence-associated NE levels, we collected dialysate samples every 10 min before, during, and after the presentation of a female. The female presence experiments consisted of three phases. Male birds were isolated 
Table 2. Summary of the quail adrenergic receptor genes and the identity of the cloned fragments compared with chicken and rat homologs

\begin{tabular}{lcccc}
\hline Source (chicken) & Chr. number (chicken) & Chr. Location (chicken) & Probe size (bp; aa position) & $\frac{\% \text { Indentity }}{\text { Chicken }}$ \\
\hline $\begin{array}{l}\text { ADR } \alpha 2 \text { A } \\
\text { NCBI Gene ID 428980 }\end{array}$ & 6 & $25,774,429-25,775,712$ & $909 ; 58-359$ & 94.94 \\
$\begin{array}{l}\text { ADR } \alpha 2 B \\
\text { NCBI Gene ID 427631 }\end{array}$ & 13 & $9,452,883-9,455,369$ & Rat & 69.04 \\
$\begin{array}{l}\text { ADR } \alpha 2 \text { Cloned } \\
\text { NCBI Gene ID 428799 }\end{array}$ & 4 & $81,141,750-81,143,378$ & $901 ; 95-393$ & 97.89 \\
\hline
\end{tabular}

Amino acid position refers to the amino acid position in relation to the chicken homolog. Chr., Chromosome; NCBI, National Center for Biotechnology Information.
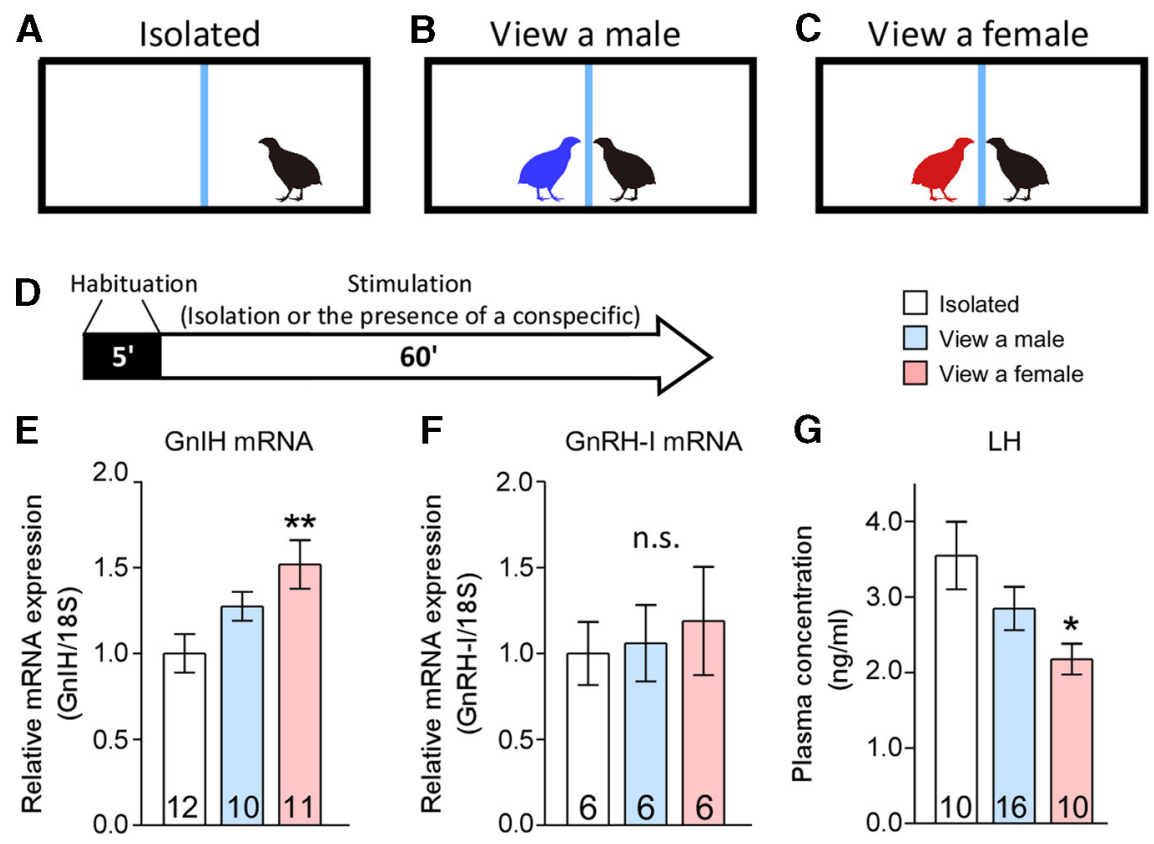

Figure 1. Effects of male or female presence on GnIH and GnRH-I mRNA expressions and plasma LH concentration in males. $\boldsymbol{A}-\boldsymbol{C}$, The experimental cages were divided in the middle with a Plexiglas wall, indicated by the blue lines. $\boldsymbol{D}$, Schematic representation of the experimental design depicting the habituation period ( $5 \mathrm{~min}$, black bar) and the stimulation period ( $60 \mathrm{~min}$, white arrow). $\boldsymbol{E}-\boldsymbol{G}$, Effects of the presence of a female on hypothalamic $\mathrm{GnIH}$ and $\mathrm{GnRH}-\mathrm{I}$ gene expressions $(\boldsymbol{E}, \boldsymbol{F})$ and circulating $\mathrm{LH}$ level $(\boldsymbol{G})$. Numbers in the bars denote the number of birds analyzed. One-way ANOVA followed by Tukey's multiple comparisons test, ${ }^{*} p<0.05,{ }^{* *} p<0.01$ versus isolated group of birds. Data are presented as mean \pm SEM.

Table 3. Acute inhibitory effect of GnIH on plasma LH concentration

\begin{tabular}{llll}
\hline Time after administration & $5 \mathrm{~min}$ & $10 \mathrm{~min}$ & $60 \mathrm{~min}$ \\
\hline Vehicle & $0.99 \pm 0.08$ & $1.11 \pm 0.10$ & $1.14 \pm 0.10$ \\
GnIH at 10 ng & $0.80 \pm 0.06$ & $0.78 \pm 0.05^{*}$ & $0.75 \pm 0.07^{* *}$
\end{tabular}

Mean \pm SEM ratio to the $L$ H value at 0 min before administration of $10 \mathrm{ng}$ of $\mathrm{GnIH}$ or vehicle $(n=9)$. ${ }^{*} p<0.05$, ${ }^{* *} p<0.01$, two-way repeated-measures ANOVA with Sidak's multiple comparisons test, vehicle versus the 10 -ng $\mathrm{GnIH}$ groups of the same time after administration.

for $30 \mathrm{~min}$ in the first phase [baseline (BL)]. After this $30 \mathrm{~min}$ period, the second phase [female presence (FP)] began, in which each male bird was presented with a female bird separated by a transparent Plexiglas wall for $60 \mathrm{~min}$. In the third phase [post (PO)], the female was removed, and male birds were isolated again for $30 \mathrm{~min}$. Samples were collected every 10 min, yielding $10 \mu \mathrm{l}$ of dialysate per sample, and they were immediately frozen $\left(-80^{\circ} \mathrm{C}\right)$ until assayed using HPLC electrochemical detection (Eicom). After the conclusion of the experiment, the birds were killed by perfusion, and the brains were removed, frozen, and sectioned $(30 \mu \mathrm{m})$ using a cryostat. Sections including the PVN were mounted on slides, and the localization of the probes was confirmed by immunohistochemistry for GnIH.

Tissue culture and NE treatment. Tissue culture was performed with a slight modification of our previous method (Chowdhury et al., 2010). To determine the effect of $\mathrm{NE}$ on $\mathrm{GnIH}$ release, diencephalic explants in- cluding GnIH neurons in the PVN and their terminals in the median eminence were collected from male birds between 10:00 A.M. and 11:30 A.M. Explants were collected into Medium 199 (catalog \#12340-030; Invitrogen) and preincubated for $90 \mathrm{~min}$ at $37^{\circ} \mathrm{C}$ in an atmosphere of $80 \% \mathrm{O}_{2}, 5 \% \mathrm{CO}_{2}$. Each diencephalic explant was then transferred to a 24-well microplate (Corning), with each well containing $1 \mathrm{ml}$ of medium supplemented with NE bitartrate salt (Sigma-Aldrich) at concentrations of $10^{-8}$ or $10^{-7} \mathrm{M}$ or vehicle only $(n=$ 5 in each group). After 60 min of incubation, each medium was collected and subjected to ELISA to quantify $\mathrm{GnIH}$ concentrations.

ELISA of GnIH. To determine the release of $\mathrm{GnIH}$ in the medium, each medium was collected and subjected to complete evaporation and reconstituted in dilution buffer $(0.1 \%$ BSA in $10 \mathrm{~mm}$ PBS, pH 7.5). Then the adjusted sample was subjected to competitive ELISA by using rabbit anti-quail $\mathrm{GnIH}$ antiserum to quantify GnIH concentrations in the medium. The specificity of GnIH antiserum has been documented previously (Tsutsui et al., 2000; Ukena et al., 2003; Ubuka et al., 2005). Quail GnIH (SIKPSAYLPLRFamide) was synthesized and used as the standard. In brief, different concentrations of $\mathrm{GnIH}$ ( $1-1000 \mathrm{pmol} / \mathrm{ml}$ ) and adjusted sample were added with the antiserum against GnIH (1:2000 dilution) to each antigen-coated well of a 96-well microplate (multiwell plate for ELISA, H-Type; Sumitomo Bakelite) and incubated for $1 \mathrm{~h}$ at room temperature. After the reaction with alkaline phosphatase (AP)-labeled goat anti-rabbit IgG (1:1000 dilution; Vector Laboratories), immunoreactive (IR) products were obtained in a substrate solution of $p$-nitrophenylphosphate (Nacalai Tesque), and the absorbance was measured at $405 \mathrm{~nm}$ on a Multiskan FC 96-well plate reader (Thermo Fisher Scientific).

Intracerebroventricular infusion of NE and blood collection. Each bird received a third-ventricular cannula as described previously (Tobari et al., 2011). Intracerebroventricular cannulation coordinates were adjusted according to a stereotaxic atlas of the Japanese quail brain (Bayle et al., 1974). A stainless steel cannula guide sleeve $(11 \mathrm{~mm}, 26$ gauge; Plastics One) was inserted to the third ventricle $(3.0 \mathrm{~mm}$ anterior, $0 \mathrm{~mm}$ lateral from the Y-point, and $7.0 \mathrm{~mm}$ deep from the surface of the dura matter). Approximately 1 week after surgery, correct placement of the cannula was confirmed by an infusion of $1 \mu \mathrm{g}$ of angiotensin-II (human; Calbiochem) dissolved in $0.9 \%$ saline. This peptide rapidly stimulates drinking behavior in birds when infused into the third ventricle (Richardson and Boswell, 1993; Tobari et al., 2011). Only the birds that immediately responded to angiotensin-II infusion by increasing their water intake were used in the experiment. Intracerebroventricular injections of $10 \mathrm{ng}, 100 \mathrm{ng}$, or $1 \mu \mathrm{g}$ of NE or vehicle into the third ventricle were performed using a $25 \mu \mathrm{l}$ microsyringe. NE bitartrate salt (Sigma-Aldrich) was dissolved in $0.9 \%$ saline. 
Birds were handheld, and an injector (11.5 $\mathrm{mm}, 33$ gauge; Plastics One) was inserted into the guide sleeve. NE or vehicle at $5 \mu \mathrm{l}$ was infused in a $60 \mathrm{~s}$ period. Quail were decapitated $60 \mathrm{~min}$ after the intracerebroventricular infusion of NE or vehicle. Blood samples were collected immediately after decapitation in heparinized centrifuge tubes.

Plasma hormone measurements. Plasma LH levels were measured following a modified version of the method described in a previous study (Sugino et al., 2002) using Europiumlabeled chicken LH (CANOMS-12442B) and rabbit anti-chicken LH serum (HAC-CH27-01RBP75) supplied by the Institute for Molecular and Cellular Regulation (Gunma University, Maebashi, Japan). It was confirmed that the antiserum cross-reacts with quail LH (Hattori and Wakabayashi, 1979; Ubuka et al., 2006). A chicken LH preparation (R1-LH-1) kindly provided by Prof. Peter Sharp (Roslin Institute, The University of Edinburgh, Scotland, UK) was used as the standard (Sharp et al., 1987).

Fluorescence immunohistochemistry and imaging. Birds were perfused through the heart with $0.1 \mathrm{M}$ PBS, followed by $4 \%$ paraformaldehyde. After postfixation and saturation with $20 \%$ sucrose, the brain was sectioned in the frontal plane at $30 \mu \mathrm{m}$. Free-floating sections were rinsed in PBS with $0.3 \%$ Triton X-100 (PBST) three times. Next, the sections were blocked with 5\% normal sheep serum in PBST for $2 \mathrm{~h}$ at room temperature. The sections were incubated with rabbit anti-bovine dopamine $\beta$-hydroxylase (DBH) antiserum (product identification \#22806; Immunostar) at a dilution of $1: 1000$ for $24 \mathrm{~h}$ at $4^{\circ} \mathrm{C}$. The specificity of this antiserum has been documented previously for use in immunohistochemistry (Bailhache and Balthazart, 1993). After rinsing, the sections were incubated in Alexa Fluor 555 goat anti-rabbit IgG (Invitrogen) in PBST at a dilution of 1:1000 for $2 \mathrm{~h}$ at room temperature.

After washing, the sections were incubated with rabbit antiserum against quail GnIH prelabeled with a Zenon Alexa Fluor 488 kit (Invitrogen) according the instructions of the manufacturer at a dilution of 1:5000 for $24 \mathrm{~h}$ at $4^{\circ} \mathrm{C}$. After washing, the sections were mounted with mounting medium and visualized by using a Nikon Ellipse E600 microscope equipped with Y-FL epifluorescence (Nikon). Every sixth section through the hypothalamus from each animal was captured with a microscopic digital camera (DP70; Olympus). GnIH neurons showing close appositions with DBH-IR fibers were counted on a computer display, and the sum of the cell number in each area was calculated.

Combination of immunohistochemistry and in situ hybridization. In situ hybridization was performed as described previously (Tobari et al., 2010, 2011) with antisense and sense RNA probes (Table 2). The sections were rinsed in $0.2 \times$ SSC for $2 \mathrm{~h}$ and then blocked for $2 \mathrm{~h}$ in a solution of $0.1 \mathrm{M}$ Tris, $\mathrm{pH} 7.5$, and $0.15 \mathrm{M} \mathrm{NaCl}$ with $10 \%$ sheep serum. The slides were incubated overnight with AP-conjugated anti-digoxigenin antibody (Roche Diagnostics) and rabbit antiserum against quail $\mathrm{GnIH}$ at a dilution of 1:1000 for $24 \mathrm{~h}$ at $4^{\circ} \mathrm{C}$. After washing, the sections were incubated for $2 \mathrm{~h}$ at room temperature in Alexa Fluor 488 goat anti-rabbit IgG (Invitrogen) at a dilution of 1:500. After washing, the AP activity was detected by adding an NBT/BCIP stock solution (Roche Diagnostics). All sections were visualized with a Nikon Ellipse E600 microscope equipped with Y-FL epifluorescence (Nikon). Every second section through the hypothalamus from each animal was captured with a microscopic digital camera (DP70; Olympus). GnIH neurons expressing adrenergic receptor
B

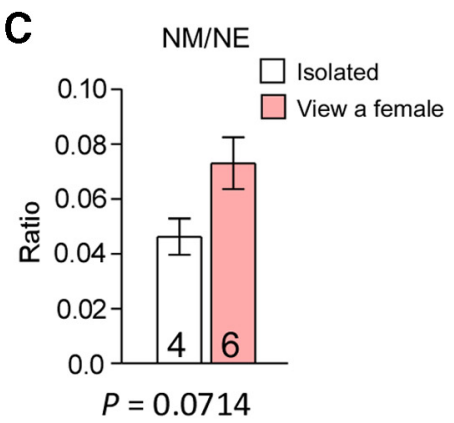

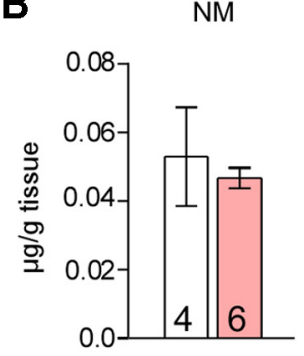

E
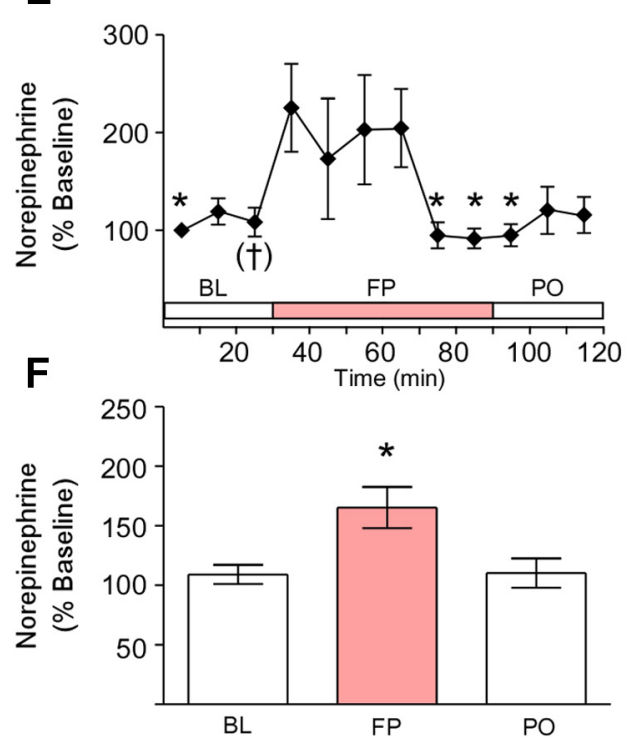

Figure 2. Effects of a female presence on diencephalic NE and NM concentration, NM/NE ratio, and NE release in the PVN of males. $\boldsymbol{A}-\boldsymbol{C}$, Effects of a female presence on diencephalic NE concentration $(\boldsymbol{A})$, NM concentration $(\boldsymbol{B})$, and NM/NE ratio (C). Data are presented as mean \pm SEM. Numbers in the bars denote the number of birds analyzed. Unpaired $t$ test, ${ }^{*} p<$ . ${ }^{*} p<0.05$ versus just after seeing a female. $n=6$. $F$, Mean changes in NE released in the PVN during BL, FP, and P0. One-way ANOVA followed by Tukey's multiple comparisons test, ${ }^{*} p<0.05$ versus BL and PO.

Table 4. Effects of a female presence on the levels of monoamines and their ratios to the parent amine in the diencephalon of males

\begin{tabular}{lcc}
\hline Monoamine & Isolated & View a female \\
\hline Concentration $(\mu \mathrm{g} / \mathrm{g}$ tissue) & & \\
DA & $0.32 \pm 0.04(5)$ & $0.31 \pm 0.04(6)$ \\
DOPAC & $0.035 \pm 0.011(4)$ & $0.028 \pm 0.002(6)$ \\
Epi & $0.30 \pm 0.06(5)$ & $0.19 \pm 0.04(6)$ \\
5-HIAA & $0.052 \pm 0.011(4)$ & $0.048 \pm 0.002(6)$ \\
5-HT & $1.12 \pm 0.15(5)$ & $0.83 \pm 0.08(6)$ \\
HVA & $0.049 \pm 0.011(4)$ & $0.046 \pm 0.004(6)$ \\
MHPG & $0.037 \pm 0.009(4)$ & $0.022 \pm 0.003(6)$ \\
NE & $1.11 \pm 0.17(5)$ & $0.69 \pm 0.09(6)$ \\
NM & $0.053 \pm 0.014(4)$ & $0.047 \pm 0.003(6)$ \\
Ratio & & \\
DOPAC/DA & $0.10 \pm 0.01(4)$ & $0.10 \pm 0.01(6)$ \\
5-HIAA/5-HT & $0.048 \pm 0.005(4)$ & $0.061 \pm 0.006(6)$ \\
HVA/DA & $0.15 \pm 0.02(4)$ & $0.16 \pm 0.02(6)$ \\
MHPG/Epi & $0.13 \pm 0.02(4)$ & $0.12 \pm 0.02(6)$ \\
MHPG/NE & $0.032 \pm 0.002(4)$ & $0.032 \pm 0.002(6)$ \\
NM/NE & $0.046 \pm 0.007(4)$ & $0.073 \pm 0.009(6)$ \\
\hline
\end{tabular}

Data are means \pm SEM. Numbers in parentheses denote the number of birds analyzed. 

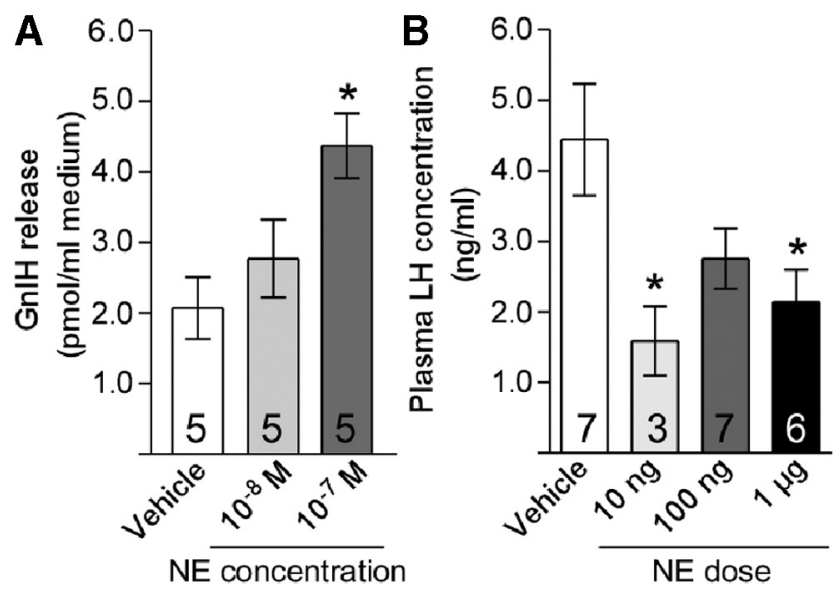

Figure 3. NE stimulates $\mathrm{G} n \mathrm{H} H$ release and decreases plasma $\mathrm{LH}$ concentration. $\boldsymbol{A}$, Effects of NE administration on the release of GnIH from diencephalic explants. Diencephalic tissue explants were treated with the indicated concentrations of NE for $60 \mathrm{~min}$. One-way ANOVA followed by Tukey's multiple comparisons test, ${ }^{*} p<0.05$ versus vehicle. $\boldsymbol{B}$, Effects of intracerebroventricular injection of NE (10 ng, $100 \mathrm{ng}$, or $1 \mu \mathrm{g}$ of NE or vehicle) on plasma LH level. One-way ANOVA followed by Dunnett's multiple comparisons test, ${ }^{*} p<$ 0.05 versus vehicle.

(ADR) $\alpha 2 \mathrm{~A}$ mRNA were counted on a computer display, and the sum of the cell number in each area was calculated.

Statistical analyses. GraphPad Prism 4/6 software (GraphPad Software) or KaleidaGraph version 4.0 (Synergy Software) was used to perform the statistics. Results were compared using either Student's $t$ test or one-way ANOVA as appropriate. Significant effects in the ANOVA were further analyzed by post hoc testing using the Tukey's or Dunnett's multiple comparison test. In the experiment of transcardiac GnIH administration, all data were converted to the ratio to $\mathrm{LH}$ value at $0 \mathrm{~min}$ before administration of $10 \mathrm{ng}$ of $\mathrm{GnIH}$ or vehicle. Data were analyzed by twoway ANOVA (group vs time course) with repeated measures on time course. Because the two-way ANOVA detected the effect of group on LH ratio, we performed Sidak's multiple comparisons test to examine the significance of differences between vehicle and 10-ng GnIH groups of the same time after administration. In the experiment of microdialysis, the first $10 \mathrm{~min}$ samples were used as the baseline measurement, and all values were converted to the percentage of the first baseline period. Data of microdialysis were also analyzed by one-way repeated-measures ANOVA through 12 time points with Dunnett's post hoc test. Differences were considered significant when $p<0.05$. All data are presented as mean \pm SEM.

\section{Results}

A female presence increased GnIH mRNA expression in the brain and decreased $\mathrm{LH}$ concentration in the plasma in male We first conducted experiments to test whether a female presence modifies $\mathrm{GnRH}$ or $\mathrm{GnIH}$ precursor mRNA expression in male quail. The basic experimental paradigm used in this study for assessing the effects of a male or female presence is shown in Figure $1 A-D$. GnIH mRNA expression differed significantly between the groups $\left(F_{(2,64)}=5.172, p=0.0118\right.$ by one-way ANOVA; Fig. 1E). Post hoc analysis indicated that the GnIH mRNA level was higher in males that were visually exposed to a female across a Plexiglas wall for $1 \mathrm{~h}$ compared with isolated males $(p<0.01)$. Conversely, there was no difference in GnRH mRNA levels between the groups $\left(F_{(2,34)}=0.1538\right.$, $p=0.8588$ by one-way ANOVA; Fig. $1 F)$. These data suggest that a female presence induces upregulation of $\mathrm{GnIH}$ gene expression in the hypothalamus. To determine the functional significance of a female presence on $\mathrm{GnIH}$ neuronal plasticity, changes in plasma $\mathrm{LH}$ concentrations were quantified. $\mathrm{LH}$ concentration differed significantly between the groups $\left(F_{(2,70)}=3.85, p=0.0318\right.$ by one-way ANOVA; Fig. $\left.1 G\right)$. Post hoc analysis indicated that plasma LH concentration was lower in males that were visually exposed to a female for $1 \mathrm{~h} \mathrm{com-}$ pared with isolated males $(p<0.05)$. Our previous study has demonstrated that peripherally administered $\mathrm{GnIH}$ by osmotic pumps can decrease plasma $\mathrm{LH}$ and testosterone concentrations in 2 weeks (Ubuka et al., 2006), but acute inhibitory effect of $\mathrm{GnIH}$ on plasma LH concentration of male quail was not known. There was a significant effect of group (vehicle vs 10-ng GnIH groups) for plasma LH concentration $\left(F_{(1,16)}=14.60, p=0.0015\right.$ by two-way repeated-measures ANOVA) but no significant effect of time course $\left(F_{(2,32)}=\right.$ $0.3153, p=0.7318)$ and interaction of the two factors $\left(F_{(2,32)}\right.$ $=1.027, p=0.3696)$. Intravenous administration of $\mathrm{GnIH}$ in free-moving quail decreased LH concentration in the plasma 10 and $60 \mathrm{~min}$ after administration $(10 \mathrm{~min}, p<0.05$; $60 \mathrm{~min}$, $p<0.01$ by Sidak's multiple comparisons test; Table 3 ).

\section{A female presence increases NE release in the PVN of males}

We further investigated the mechanism of how a female presence stimulates the activity of GnIH neurons. Previous studies have suggested that monoamines are involved in the processing of social information to modify reproductive functions (Naumenko et al., 1987; Cornil et al., 2005). Therefore, we investigated whether the presence of a female changes the concentration of monoamines in the diencephalon of male birds. The mean concentrations of monoamines (NE, Epi, DA, and 5-HT) and their metabolites (DOPAC, 5-HIAA, HVA, MHPG, and NM) and their ratio to the parent amine in the diencephalon were analyzed by HPLC combined with the electrochemical detection method. The mean NE concentration was significantly decreased by $37.9 \%$ in subjects exposed to a female compared with males studied in the absence of a female $(t=2.288, p=0.0479$ by unpaired $t$ test; Fig. $2 A)$. The NM/NE ratio tended to increase by viewing a female $(t=2.078, p=$ 0.0714 by unpaired $t$ test; Fig. $2 C$ ). There was no statistical difference in other amines or metabolites and their ratios to their parent amines ( $p>0.05$ by unpaired $t$ test or unpaired $t$ test with Welch's correction; Fig. 2B, Table 4 ).

To elucidate whether the decrease in the concentration of NE in the diencephalon reflects increased release in the PVN, in which $\mathrm{GnIH}$ neuronal cell bodies exist, we performed in vivo microdialysis in the PVN of males investigating extracellular NE release in the presence of a female. Histological examination of sections for probe placement in the PVN showed that the probe was successfully placed within the PVN (Fig. 2D). One-way repeated-measures ANOVA of change from initial baseline revealed a significant effect of a female presence $\left(\mathrm{F}_{(11,55)}=2.546\right.$, $p=0.0112$; Fig. $2 E$ ) on extracellular NE levels in the PVN. Extracellular NE levels in the PVN immediately started to increase after seeing a female bird ( $p=0.0748$, just before vs after seeing a female by Dunnett's multiple comparison test; Fig. 2E) and maintained its high level for $\sim 30 \mathrm{~min}$. The NE level decreased from its highest level and returned to baseline level after $30 \mathrm{~min}$ while in FP (Fig. 2E). One-way ANOVA detected a significant effect of phase (BL, FP, and PO; $\left.F_{(2,34)}=6.070, p=0.0117\right)$. Post hoc analyses revealed that NE significantly increased in FP compared with $\mathrm{BL}$ and $\mathrm{PO}$ ( $p<0.05$ by Tukey's multiple comparison test; Fig. 2F). 


\begin{abstract}
NE stimulates the release of GnIH from the hypothalamus in vitro and inhibits plasma LH secretion

We assessed the effect of NE on GnIH release from diencephalons collected from male quail. There was a significant effect of treatment $\left(F_{(2,28)}=5.889, p=0.0165\right.$ by one-way ANOVA). Treatment of diencephalons for $60 \mathrm{~min}$ with $10^{-7} \mathrm{M} \mathrm{NE}$ stimulated the release of $\mathrm{GnIH}(p<0.05$ vs vehicle by Tukey's multiple comparison test; Fig. 3A). We then tested the effect of intracerebroventricular administration of $\mathrm{NE}$ on $\mathrm{LH}$ secretion. Male quail were intracerebroventricularly injected with $\mathrm{NE}(0,10$, or $100 \mathrm{ng}$ or $1 \mu \mathrm{g})$. There was a significant effect of treatment $\left(F_{(3,66)}=\right.$ $3.819, p=0.0269$ by one-way ANOVA). Ten nanograms and $1 \mu \mathrm{g}$ of NE reduced plasma LH concentrations $60 \mathrm{~min}$ after administration ( $p<0.05$ vs vehicle by Dunnett's multiple comparison test; Fig. $3 B$ ).
\end{abstract}

\section{Noradrenergic neurons project to $\mathrm{GnIH}$ neurons that express ADR $\alpha 2 \mathrm{~A}$}

To investigate whether NE can directly control GnIH neurons, noradrenergic innervation and expression of adrenergic receptor on $\mathrm{GnIH}$ neurons were further studied. We applied the doubleimmunostaining method to the frontal brain sections of male birds using antibodies against the NE neuronal marker, $\mathrm{DBH}$ and $\mathrm{GnIH}$ peptide. Fluorescence microscopy indicated the anatomical relationship between DBH-IR fibers and GnIH-IR neurons (Fig. 4A-D). DBH-IR fibers existed in close proximity to GnIH-IR cell bodies (Fig. 4E) and the dendrite of a GnIH neuron (Fig. $4 F$ ) in the PVN of male quail. Quantitative analysis showed $13.0 \pm 2.0 \%$ of $\mathrm{GnIH}$ neuronal somata with close contact of the noradrenergic fibers. It is known that NE acting through $\operatorname{ADR} \alpha$ is involved in the regulation of LH (Buonomo et al., 1981; Leung et al., 1982; Goodman, 1989; Gore and Terasawa, 2001). High density of ADR $\alpha 2$ binding is present in the hypothalamic areas including the PVN in quail (Ball et al., 1989). Therefore, we investigated whether $\mathrm{ADR} \alpha 2$ is expressed in the PVN by in situ hybridization. Three subtypes of ADR $\alpha 2$ $(\mathrm{ADR} \alpha 2 \mathrm{~A}, \mathrm{ADR} \alpha 2 \mathrm{~B}$, and $\mathrm{ADR} \alpha 2 \mathrm{C})$ are known in birds (Diez-Alarcia et al., 2009). We cloned $\mathrm{ADR} \alpha 2 \mathrm{~A}$ and $\mathrm{ADR} \alpha 2 \mathrm{C}$ cDNAs in the diencephalon, and they were used as the templates to make probes for in situ hybridization. Intense expression of $\mathrm{ADR} \alpha 2 \mathrm{~A}$ mRNA was distributed in the PVN (Fig. 5A). Moderate signals for ADR $\alpha 2 \mathrm{C}$ mRNA were also found in the PVN (Fig. 5C). Controls in which the sense RNA probes were substituted for the antisense RNA probes showed no positive signal in any of the brain sections (Fig. $5 B, D)$. To investigate whether ADR $\alpha 2$ mRNAs and GnIH are
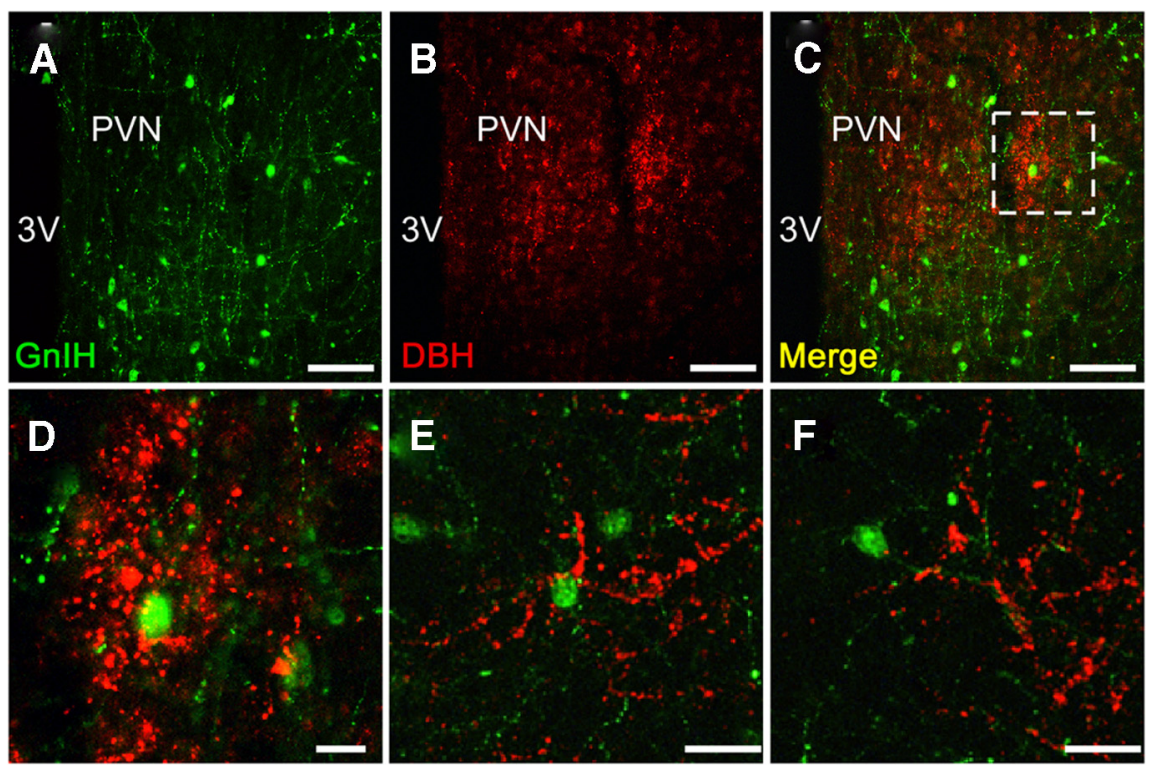

Figure 4. Noradrenergic neurons project to $\mathrm{GnlH}$ neurons. Example of double-immunofluorescent staining for $\mathrm{GnlH}$ and DBH immunoreactivities in the PVN from two male quail. Representative fluorescent photomicrographs showing $\mathrm{GnIH}(\boldsymbol{A} ;$ green $)$ and $\mathrm{DBH}(\boldsymbol{B}$; red). Merged image of $\boldsymbol{A}$ and $\boldsymbol{B}(\boldsymbol{C})$. D shows higher magnification of the boxed area in $\boldsymbol{C}$. Another example of $\mathrm{Gn} I \mathrm{H}$ perikarya and dendrites in the PVN ( $\boldsymbol{E}$ and $\boldsymbol{F}$ are from the same bird). Similar results were obtained in repeated experiments by using three different birds. 3V, Third ventricle. Scale bars: $\boldsymbol{A}-\boldsymbol{C}, 50 \mu \mathrm{m} ; \boldsymbol{D}, 10 \mu \mathrm{m} ; \boldsymbol{E}, \boldsymbol{F}, 20 \mu \mathrm{m}$.
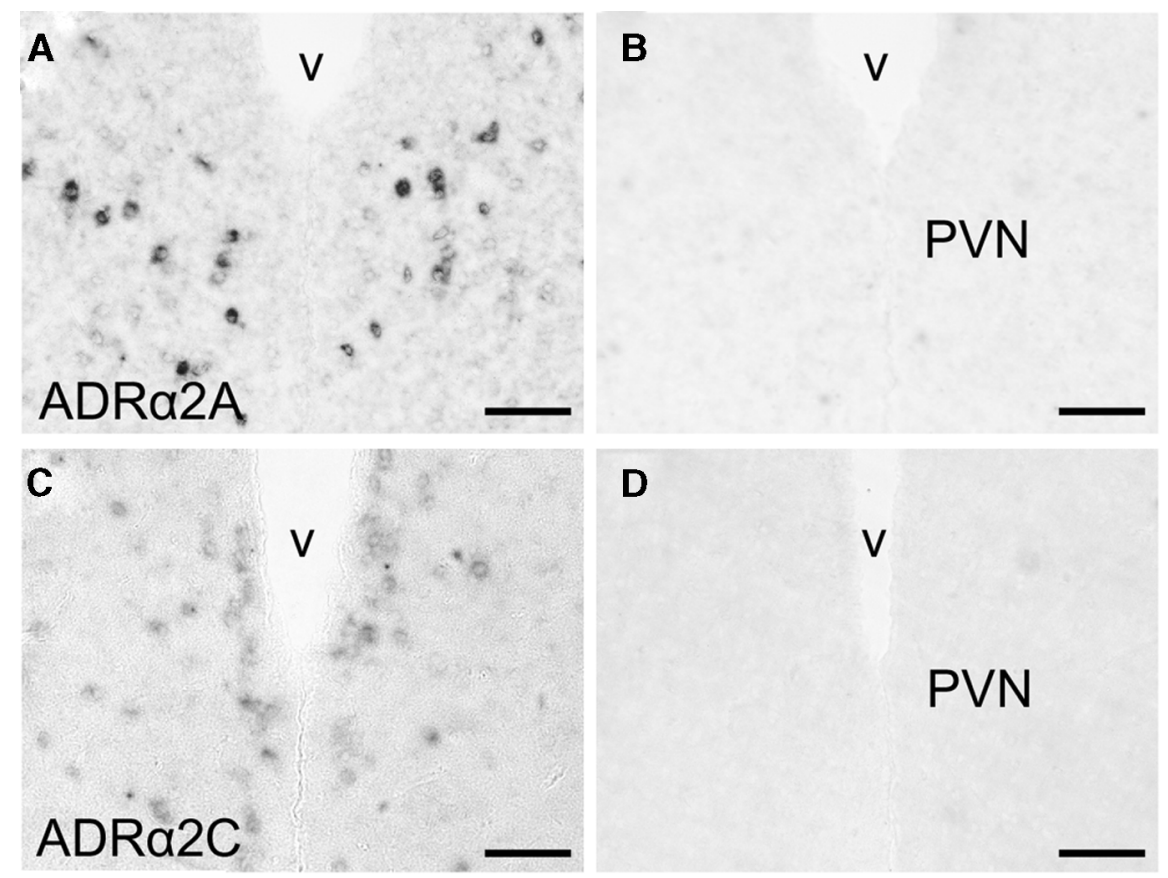

Figure 5. $A D R \alpha 2 A$ and $A D R \alpha 2 C$ mRNA expression patterns in the PVN. Representative sections of $A D R \alpha 2 A$ and $A D R \alpha 2 C$ mRNA expressions as detected by in situ hybridization. $\boldsymbol{A}, \boldsymbol{C}$, Hybridization with an antisense ADR $\alpha 2 A$ or ADR $\alpha 2$ p probe demonstrates ADR $\alpha 2 A$ or ADR $\alpha 2 C$ mRNA expression. $B, D$, Hybridization with sense ADR $\alpha 2 A$ or ADR $\alpha 2 C$ probe serves as a negative control for antisense probe specificity. $v$, Third ventricle. Scale bars, $50 \mu \mathrm{m}$.

colocalized, immunohistochemistry for $\mathrm{GnIH}$ was further conducted using the same sections used for in situ hybridization of $\mathrm{ADR} \alpha 2$ mRNAs. Cellular analysis revealed that $\mathrm{ADR} \alpha 2 \mathrm{~A}$ mRNA was expressed in GnIH-IR neurons (Fig. 6A-C). Quantitative analysis from three different birds showed that $24.1 \pm 4.0 \%$ of GnIH-IR cells clearly expressed the ADR $\alpha 2 \mathrm{~A}$ mRNA. It was also shown that $\mathrm{ADR} \alpha 2 \mathrm{C}$ mRNA and $\mathrm{GnIH}$ are not colocalized in the brain. 

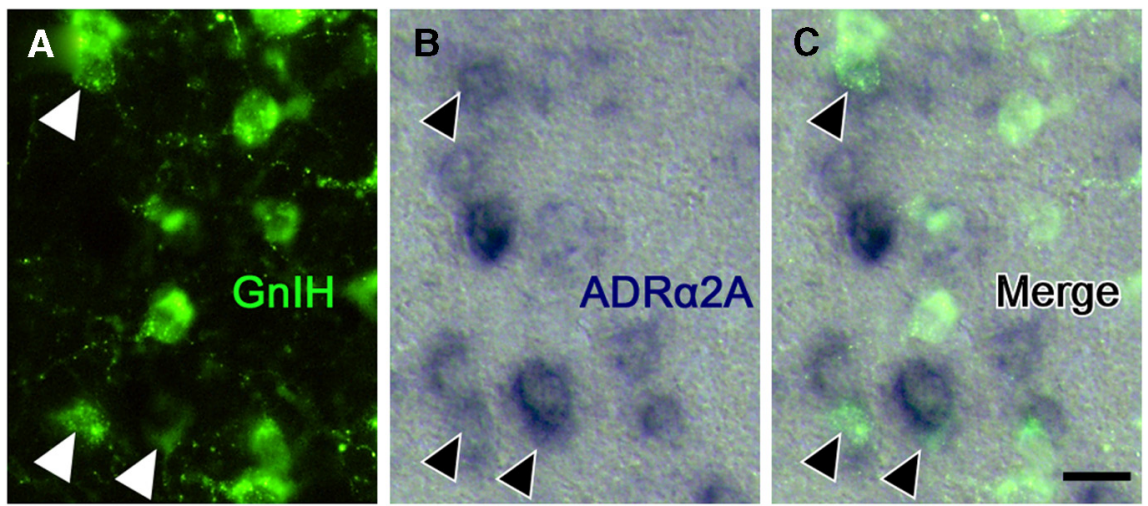

Figure 6. GnIH neurons express ADR $\alpha 2 A$. Double staining by immunohistochemistry against $\mathrm{GnIH}$ peptide $(\boldsymbol{A})$, in situ hybridization for ADR $\alpha 2 A$ mRNA $(\boldsymbol{B})$, and the merged image $(\boldsymbol{C})$. Arrowheads indicate neurons coexpressing $\mathrm{GnlH}$ (green fluorescence) and ADR $\alpha 2 A$ mRNA (blue). Scale bar, $10 \mu \mathrm{m}$. Similar results were obtained in repeated experiments by using three different birds.

\section{Discussion}

Despite the profound influence of social interaction on the reproductive axis in all vertebrates, less is known about how social information influences the hypothalamic-pituitarygonadal (HPG) axis at the molecular level, and there are still many unanswered questions about links between reproductive functions and social behaviors. Our study demonstrates for the first time that a female presence increases $\mathrm{GnIH}$ release by stimulating extracellular NE release in the PVN, resulting in the suppression of plasma LH concentrations in sexually active male quail. It was established in male Japanese quail that the presence of a female bird rapidly decreases plasma testosterone level (Delville et al., 1984; Cornil et al., 2009). These decreases in plasma $\mathrm{LH}$ and testosterone levels of male quail after seeing a female is exceptional within most vertebrate species, in which increases in plasma LH and testosterone generally follow after interaction with a female (Feder et al., 1977; Coquelin and Bronson, 1979; Harding, 1981; O'Connell et al., 1981; Moore, 1982, 1983; Runfeldt and Wingfield, 1985; Dufty and Wingfield, 1986; Pinxten et al., 2003; Amstislavskaya and Popova, 2004).

Monoamines are thought to play important roles in the regulation of behaviors in response to potential mate's cues (e.g., arousal, attention, and goal-directed approach responses; AstonJones et al., 2000; Berridge and Waterhouse, 2003; Riters and Pawlisch, 2007; Riters et al., 2007). In the present study, we measured tissue concentrations of the amines and their major metabolites in the diencephalons of male quail, and we found a decrease in NE level and a nearly significant increase in the NM/NE ratio after visual interactions with a female. To elucidate whether the decrease in NE concentration in the tissue reflected decreased synthesis of $\mathrm{NE}$ or increased release of $\mathrm{NE}$, we performed in vivo microdialysis in the PVN of males in the presence of a female. Using a flow rate of $1 \mu \mathrm{l} / \mathrm{min}$ collected at $10 \mathrm{~min}$ intervals, we found a nearly significant increase in NE levels in the PVN of male quail immediately after seeing a female, and the high NE level was maintained for $\sim 30 \mathrm{~min}$. However, the high NE level returned to baseline level after 30 min even if a female bird was present across a Plexiglas wall. These results suggest that the presence of the female induces NE release only transiently in the PVN of males.

We also investigated the effect of a female presence on GnRH-I and GnIH systems of sexually active male quail. Visual perception of a female rapidly stimulated hypothalamic $\mathrm{GnIH}$ gene expression in males. Conversely, we did not find a signifi- cant effect of a female presence on GnRH-I gene expression in the male quail brain despite suppression of plasma LH concentration. This lack of change in GnRH-I gene expression is consistent with previous reports indicating that plasticity in GnRH-I expression in quail is negligible (Teruyama and Beck, 2000; MacDougall-Shackleton et al., 2009). These findings suggest that inhibitory effects of a female presence on circulating gonadotropin occur via stimulation of $\mathrm{GnIH}$ release. In avian species, $\mathrm{GnIH}$ fibers extend to the median eminence (Tsutsui et al., 2000; Ukena et al., 2003; Ubuka et al., 2008; Tobari et al., 2010), and $\mathrm{GnIH}$ receptors are expressed in the pituitary gland (Yin et al., 2005). In this study, we also clarified that GnIH acutely decreases plasma LH level of male quail. Together, these results suggest that GnIH may acutely regulate the HPG axis of sexually active males by influencing pituitary gonadotropin release. This study suggests that GnIH could play an important role in the rapid regulation of the HPG axis by social stimuli in sexually active male birds during the breeding season.

NE appears to mediate a heightened state of arousal and attention to changes in the environment and to speciesspecific stimuli (Waterman and Harding, 2008). NE is also known as an important regulator of $\mathrm{LH}$ secretion in male birds (Buonomo and Scanes, 1983; Balthazart and Ball, 1989). Central NE-producing cell bodies form cell groups that are located in the brainstem. The locus ceruleus is the largest of these with the remaining cell groups forming the lateral tegmental system (LT). In general, projections of the LT are restricted to thalamic and hypothalamic brain regions (Fillenz, 1990). In the quail brain, DBH-IR perikarya are exclusively located in the lower brainstem, in the pons, and to a smaller extent in the medulla (Bailhache and Balthazart, 1993). A prominent DBH-IR innervation is observed in the rostral PVN of the quail brain (Bailhache and Balthazart, 1993). The concentration of NE in the hypothalamus is high compared with other brain areas (Ottinger and Balthzart, 1987; Balthazart et al., 1988). Autoradiographic experiments using the $\alpha 2$-adrenergic ligand $p$-aminoclonidine have revealed high receptor density in the PVN (Ball et al., 1989) and that ADR $\alpha 2$ s are thought to be postsynaptic in the hypothalamus (Balthazart and Ball, 1989). Thus, it is possible that NE is the mediator of the effect of a female presence on GnIH release. In this study, the release of $\mathrm{GnIH}$ from diencephalic tissue block was measured in response to NE, and intracerebroventricular administration of a relatively low dose of $\mathrm{NE}$ ( $10 \mathrm{ng}$ and $1 \mu \mathrm{g}$ ) decreased plasma LH concentration in male quail. We further found close apposition of noradrenergic fibers in the vicinity of GnIH neurons in the PVN. $\mathrm{ADR} \alpha 2 \mathrm{~A}$ mRNA was expressed in $\mathrm{GnIH}$ neurons, suggesting that $\mathrm{NE}$ exerts a direct effect on $\mathrm{GnIH}$ neurons through $\mathrm{ADR} \alpha 2 \mathrm{~A}$. Therefore, our results strongly suggest that a female presence rapidly decreases LH by increasing extracellular NE release in the PVN that stimulates $\mathrm{GnIH}$ activity via $\mathrm{ADR} \alpha 2 \mathrm{~A}$.

In conclusion, our results indicate that a female presence increases $\mathrm{GnIH}$ neuronal activity by stimulating NE release in the $\mathrm{PVN}$, resulting in the suppression of plasma $\mathrm{LH}$ of sexually active males. This NE-GnIH system is a novel neurochemical pathway 
through which social milieu can rapidly influence reproductive physiology in quail.

\section{References}

Amstislavskaya TG, Popova NK (2004) Female-induced sexual arousal in male mice and rats: behavioral and testosterone response. Horm Behav 46:544-550. CrossRef Medline

Aston-Jones G, Rajkowski J, Cohen J (2000) Locus coeruleus and regulation of behavioral flexibility and attention. Prog Brain Res 126:165-182. CrossRef Medline

Bailhache T, Balthazart J (1993) The catecholaminergic system of the quail brain: immunocytochemical studies of dopamine $\beta$-hydroxylase and tyrosine hydroxylase. J Comp Neurol 329:230-256. CrossRef Medline

Ball GF, Balthazart J (2010) Japanese quail as a model system for studying the neuroendocrine control of reproductive and social behaviors. ILAR J 51:310-325. CrossRef Medline

Ball GF, Nock B, McEwen BS, Balthazart J (1989) Distribution of alpha 2 -adrenergic receptors in the brain of the Japanese quail as determined by quantitative autoradiography: implications for the control of sexually dimorphic reproductive processes. Brain Res 491:68-79. CrossRef Medline

Balthazart J, Ball GF (1989) Effects of the noradrenergic neurotoxin DSP-4 on luteinizing hormone levels, catecholamine concentrations, $\alpha_{2}$ adrenergic receptor binding, and aromatase activity in the brain of the Japanese quail. Brain Res 492:163-175. CrossRef Medline

Balthazart J, Libioulle JM, Sante P (1988) Stimulatory effects of the noradrenergic neurotoxin DSP4 on sexual behavior in male quail. Behav Proc 17:27-44. CrossRef Medline

Bayle JD, Ramade F, Oliver J (1974) Stereotaxic topography of the brain of the quail (Coturnix coturnix japonica). J Physiol (Paris) 68:219-241. Medline

Berridge CW, Waterhouse BD (2003) The locus coeruleus-noradrenergic system: modulation of behavioral state and state-dependent cognitive processes. Brain Res Rev 42:33-84. CrossRef Medline

Buonomo FC, Scanes CG (1983) Pharmacological studies on the noradrenergic control of luteinizing hormone secretion in the domestic fowl. Gen Comp Endocrinol 49:358-363. CrossRef Medline

Buonomo FC, Rabii J, Scanes CG (1981) Aminergic involvement in the control of luteinizing hormone secretion in the domestic fowl. Gen Comp Endocrinol 45:162-166. CrossRef Medline

Burgus R, Ling N, Butcher M, Guillemin R (1973) Primary structure of somatostatin, a hypothalamic peptide that inhibits the secretion of pituitary growth hormone. Proc Natl Acad Sci U S A 70:684-688. CrossRef Medline

Calisi RM, Díaz-Muñoz SL, Wingfield JC, Bentley GE (2011) Social and breeding status are associated with the expression of GnIH. Genes Brain Behav 10:557-564. CrossRef Medline

Chowdhury VS, Yamamoto K, Ubuka T, Bentley GE, Hattori A, Tsutsui K (2010) Melatonin stimulates the release of gonadotropin-inhibitory hormone by the avian hypothalamus. Endocrinology 151:271-280. CrossRef Medline

Coquelin A, Bronson FH (1979) Release of luteinizing hormone in male mice during exposure to females: habituation of the response. Science 206:1099-1101. CrossRef Medline

Cornil CA, Dalla C, Papadopoulou-Daifoti Z, Baillien M, Dejace C, Ball GF, Balthazart J (2005) Rapid decreases in preoptic aromatase activity and brain monoamine concentrations after engaging in male sexual behavior. Endocrinology 146:3809-3820. CrossRef Medline

Cornil CA, Stevenson TJ, Ball GF (2009) Are rapid changes in gonadal testosterone release involved in the fast modulation of brain estrogen effects? Gen Comp Endocrinol 163:298-305. CrossRef Medline

Delville Y, Sulon J, Hendrick JC, Balthazart J (1984) Effect of the presence of females on the pituitary-testicular activity in male Japanese quail (Coturnix coturnix japonica). Gen Comp Endocrinol 55:295-305. CrossRef Medline

Diez-Alarcia R, Mostany R, Dos-Anjos S, Fernández-López A (2009) Functional autoradiography and gene expression analysis applied to the characterization of the $\alpha 2$-adrenergic system in the chicken brain. J Chem Neuroanat 38:282-291. CrossRef Medline

Dufty AM Jr, Wingfield JC (1986) The influence of social cues on the reproductive endocrinology of male brown-headed cowbirds: field and laboratory studies. Horm Behav 20:222-234. CrossRef Medline

Feder HH, Storey A, Goodwin S, Reboulleau C, Silver R (1977) Testosterone and " $5 \alpha$-dihydrotestosterone" levels in peripheral plasma of male and female ring doves (Streptopelia risoria) during the reproductive cycle. Biol Reprod 16:666-677. CrossRef Medline

Fillenz M (1990) Noradrenrgic neurons. New York: Cambridge UP.

Fuchs E, Kramer M, Hermes B, Netter P, Hiemke C (1996) Psychosocial stress in tree shrews: clomipramine counteracts behavioral and endocrine changes. Pharmacol Biochem Behav 54:219-228. CrossRef Medline

Goodman RL (1989) Functional organization of the catecholaminergic neural systems inhibiting luteinizing hormone secretion in anestrous ewes. Neuroendocrinology 50:406-412. CrossRef Medline

Gore AC, Terasawa E (2001) Neural circuits regulating pulsatile luteinizing hormone release in the female guinea-pig: opioid, adrenergic and serotonergic interactions. J Neuroendocrinol 13:239-248. CrossRef Medline

Harding CF (1981) Social modulation of circulating hormone levels in the male. Am Zool 21:223-231.

Hattori M, Wakabayashi K (1979) Isoelectric focusing and gel filtration studies on the heterogeneity of avian pituitary luteinizing hormone. Gen Comp Endocrinol 39:215-221. CrossRef Medline

Korzan WJ, Summers TR, Summers CH (2000) Monoaminergic activities of limbic regions are elevated during aggression: influence of sympathetic social signaling. Brain Res 870:170-178. CrossRef Medline

Korzan WJ, Robison RR, Zhao S, Fernald RD (2008) Color change as a potential behavioral strategy. Horm Behav 54:463-470. CrossRef Medline

Kriegsfeld LJ, Mei DF, Bentley GE, Ubuka T, Mason AO, Inoue K, Ukena K, Tsutsui K, Silver R (2006) Identification and characterization of a gonadotropin-inhibitory system in the brains of mammals. Proc Natl Acad Sci U S A 103:2410-2415. CrossRef Medline

Leung PC, Arendash GW, Whitmoyer DI, Gorski RA, Sawyer CH (1982) Differential effects of central adrenoceptor agonists on luteinizing hormone release. Neuroendocrinology 34:207-214. CrossRef Medline

Macdougall-Shackleton SA, Stevenson TJ, Watts HE, Pereyra ME, Hahn TP (2009) The evolution of photoperiod response systems and seasonal GnRH plasticity in birds. Integr Comp Biol 49:580-589. CrossRef Medline

Maruska KP, Fernald RD (2011) Social regulation of gene expression in the hypothalamic-pituitary-gonadal axis. Physiology (Bethesda) 26:412-423. CrossRef Medline

Matsunaga M, Ukena K, Baulieu EE, Tsutsui K (2004) $7 \alpha$-Hydroxypregnenolone acts as a neuronal activator to stimulate locomotor activity of breeding newts by means of the dopaminergic system. Proc Natl Acad Sci U S A 101:17282-17287. CrossRef Medline

Matsuo H, Baba Y, Nair RM, Arimura A, Schally AV (1971) Structure of the porcine LH- and FSH-releasing hormone. I. The proposed amino acid sequence. Biochem Biophys Res Commun 43:1334-1339. CrossRef Medline

Moore M (1983) Effect of female sexual displays on the endocrine physiology and behavior of male white-crowned sparrows, Zonotrichia leucophrys. J Zool 199:137-148.

Moore MC (1982) Hormonal response of free-living male White-crowned sparrows to experimental manipulation of female sexual behavior. Horm Behav 16:323-329. CrossRef Medline

Naumenko EV, Amstislavskaya TG, Osadchuk AV (1987) Involvement of the catecholamine mechanisms in the activation of mouse hypophyseotesticular complex induced by the female presence effect. Neurosci Behav Physiol 17:179-183. CrossRef Medline

O’Connell ME, Silver R, Feder HH, Reboulleau C (1981) Social interactions and androgen levels in birds. II. Social factors associated with a decline in plasma androgen levels in male ring doves (Streptopelia risoria). Gen Comp Endocrinol 44:464-469. CrossRef Medline

Ottinger MA, Balthazart J (1987) Brain monoamines and sexual behavior in Japanese quail: effects of castration and steroid replacement therapy. Behav Processes 14:197-216. CrossRef Medline

Pinxten R, de Ridder E, Eens M (2003) Female presence affects male behavior and testosterone levels in the European starling (Sturnus vulgaris). Horm Behav 44:103-109. CrossRef Medline

Richardson RD, Boswell T (1993) A method for third ventricular cannulation of small passerine birds. Physiol Behav 53:209-213. CrossRef Medline

Riters LV, Pawlisch BA (2007) Evidence that norepinephrine influences responses to male courtship song and activity within song control regions 
and the ventromedial nucleus of the hypothalamus in female European starlings. Brain Res 1149:127-140. CrossRef Medline

Riters LV, Olesen KM, Auger CJ (2007) Evidence that female endocrine state influences catecholamine responses to male courtship song in European starlings. Gen Comp Endocrinol 154:137-149. CrossRef Medline

Robinson GE, Fernald RD, Clayton DF (2008) Genes and social behavior. Science 322:896-900. CrossRef Medline

Runfeldt S, Wingfield JC (1985) Experimentally prolonged sexual activity in female sparrows delays termination of reproductive activity in their untreated mates. Anim Behav 33:403-410.

Sachs BD (1967) Photoperiodic control of the cloacal gland of the Japanese quail. Science 157:201-203. CrossRef Medline

Sharp PJ, Dunn IC, Talbot RT (1987) Sex differences in the LH responses to chicken LHRH-I and -II in the domestic fowl. J Endocrinol 115:323-331. CrossRef Medline

Sugino T, Hasegawa Y, Kikkawa Y, Yamaura J, Yamagishi M, Kurose Y, Kojima M, Kangawa K, Terashima Y (2002) A transient ghrelin surge occurs just before feeding in a scheduled meal-fed sheep. Biochem Biophys Res Commun 295:255-260. CrossRef Medline

Teruyama R, Beck MM (2000) Changes in immunoreactivity to anticGnRH-I and -II are associated with photostimulated sexual status in male quail. Cell Tissue Res 300:413-426. CrossRef Medline

Tobari Y, Iijima N, Tsunekawa K, Osugi T, Okanoya K, Tsutsui K, Ozawa H (2010) Identification of gonadotropin-inhibitory hormone in the zebra finch (Taeniopygia guttata): Peptide isolation, cDNA cloning and brain distribution. Peptides 31:816-826. CrossRef Medline

Tobari Y, Iijima N, Tsunekawa K, Osugi T, Haraguchi S, Ubuka T, Ukena K, Okanoya K, Tsutsui K, Ozawa H (2011) Identification, localisation and functional implication of 26RFa orthologue peptide in the brain of Zebra finch (Taeniopygia guttata). J Neuroendocrinol 23:791-803. CrossRef Medline

Tsutsui K (2009) A new key neurohormone controlling reproduction, gonadotropin-inhibitory hormone $(\mathrm{GnIH})$ : biosynthesis, mode of action and functional significance. Prog Neurobiol 88:76-88. CrossRef Medline
Tsutsui K, Saigoh E, Ukena K, Teranishi H, Fujisawa Y, Kikuchi M, Ishii S, Sharp PJ (2000) A novel avian hypothalamic peptide inhibiting gonadotropin release. Biochem Biophys Res Commun 275:661-667. CrossRef Medline

Tsutsui K, Bentley GE, Bedecarrats G, Osugi T, Ubuka T, Kriegsfeld LJ (2010) Gonadotropin-inhibitory hormone $(\mathrm{GnIH})$ and its control of central and peripheral reproductive function. Front Neuroendocrinol 31: 284-295. CrossRef Medline

Ubuka T, Bentley GE, Ukena K, Wingfield JC, Tsutsui K (2005) Melatonin induces the expression of gonadotropin-inhibitory hormone in the avian brain. Proc Natl Acad Sci U S A 102:3052-3057. CrossRef Medline

Ubuka T, Ukena K, Sharp PJ, Bentley GE, Tsutsui K (2006) Gonadotropininhibitory hormone inhibits gonadal development and maintenance by decreasing gonadotropin synthesis and release in male quail. Endocrinology 147:1187-1194. CrossRef Medline

Ubuka T, Kim S, Huang YC, Reid J, Jiang J, Osugi T, Chowdhury VS, Tsutsui K, Bentley GE (2008) Gonadotropin-inhibitory hormone neurons interact directly with gonadotropin-releasing hormone-I and -II neurons in European starling brain. Endocrinology 149:268-278. Medline

Ubuka T, Haraguchi S, Tobari Y, Narihiro M, Ishikawa K, Hayashi T, Harada N, Tsutsui K (2014) Hypothalamic inhibition of socio-sexual behaviour by increasing neuroestrogen synthesis. Nat Commun 5:3061. CrossRef Medline

Ukena K, Ubuka T, Tsutsui K (2003) Distribution of a novel avian gonadotropin-inhibitory hormone in the quail brain. Cell Tissue Res 312: 73-79. Medline

Waterman SA, Harding CF (2008) Neurotoxic effects of DSP-4 on the central noradrenergic system in male zebra finches. Behav Brain Res 188:271280. CrossRef Medline

Yin H, Ukena K, Ubuka T, Tsutsui K (2005) A novel G protein-coupled receptor for gonadotropin-inhibitory hormone in the Japanese quail (Coturnix japonica): identification, expression and binding activity. J Endocrinol 184:257-266. CrossRef Medline 